\title{
Management of Warfarin Complications In The
}

\section{Emergency Department}

\author{
Warfarin Komplikasyonlarının Acil Serviste Yönetimi \\ Mahmut Özdemir $^{{ }^{*}}$, Emin Asoğlư ${ }^{2}$, Nesim Aladağ ${ }^{3,}$ Ramazan Asoğlư $^{4}$, Gizem Gizli ${ }^{5}$ \\ ${ }^{1}$ Kolan Hospital, Cardiology Department, İstanbul, Turkey \\ ${ }^{2}$ Mardin Community Hospital, Cardiology Department, Mardin, Turkey \\ ${ }^{3} \mathrm{~V}$ an Training and Research Hospital, Cardiology Department, Van, Turkey \\ ${ }^{4}$ Adryaman University Training and Research Hospital, Cardiology Department, Adiyaman, Turkey \\ ${ }^{5}$ Yuzuncu Yil University, Department of Emergency Medicine, Van, Turkey
}

\begin{abstract}
Background: Bleeding is the risk related to long-term warfarin therapy and rises significantly at INR values above 4.5. The goal of warfarin reversal is to elevate vitamin Kdependent clotting factors. The aim of this study was to evaluate the management of the warfarin related bleeding complications in acute care patients.

Material and Method: A totally of 74 patients with on warfarin treatment, who admitted to our acute care clinic were enrolled to the study. The patients were grouped into three groups based on International normalized ratio (INR) levels. INR levels of the groups were $<3.0$ for Group-I, $3.0 \leq$ INR $\leq 5.0$ for Group-II and INR>5.0 for Group-III. Patients' medical history, medications and warfarin related complications were recorded throughout examination.

Results: In hematological analysis, platelet count and mean platelet volume were similar between groups. Plateletcrit and hemoglobin levels were significantly higher in group-I than group-III $(p=0.01)$. There was no significance difference between groups in blood group analysis. Group-I and groupII were evaluated without medical intervention yet fresh frozen plasma (FFP) and erythrocyte suspension (ES) were given significantly in group-III. Patients in group-I and groupII were discharged usually, and group-III subjects were followed-up in the hospital.

Conclusion: This study demonstrated that warfarin anticoagulation at higher INR levels and without bleeding complication was managed by conservatively. Intravenous vitamin $\mathrm{K}$ was administered at minor bleeding complications in patients with warfarin anticoagulation. FFP and vitamin $\mathrm{K}$ was administered at the high INR levels with major bleeding complications in patients with warfarin anticoagulation.
\end{abstract}

Key Words: Warfarin, bleeding, anticoagulation, vitamin K

\section{ÖZET}

Amaç: Kanama, uzun süreli warfarin tedavisine bağlı bir risktir ve 4.5 'in üzerindeki uluslararası normalleştirilmiş oran (INR) değerlerinde belirgin şekilde artmaktadır. Warfarinin etkisini azaltmadaki amaç $\mathrm{K}$ vitaminine bağlı prhtılaşma faktörlerini yükseltmektir.

$\mathrm{Bu}$ çalışmanın amacı acil servis hastalarında warfarine bağlı kanama komplikasyonlarının tedavisini değerlendirmektir.

Gereç ve Yöntem: Warfarin tedavisi almakta olan ve acil servis kliniğimize başvuran toplam 74 hasta çalışmaya dahil edildi. Hastalar uluslararası normalleştirilmiş oran (INR) seviyelerine göre üç gruba ayrıldı. Grupların INR düzeyleri grup-1 için $<3.0$, grup-2 için $3.0 \leq \mathrm{INR} \leq 5.0$, grup-3 için $5>$ idi. Hastaların tıbbi öyküleri, kullandığ 1 ilaçlar ve warfarine bağlı komplikasyonlar muayene sirasında kayıt altına alındı.

Bulgular: Hematolojik analizde trombosit sayisı ve ortalama trombosit hacmi gruplar arasinda benzerdi. Plateletkrit ve hemoglobin düzeyleri grup I'de grup III'e göre anlamlı derecede yüksekti $(\mathrm{p}=0.01)$. Kan grubu analizinde gruplar arasinda anlamli fark yoktu Grup-I ve grup-II tıbbi müdahale olmadan değerlendirildi, ancak taze donmuş plazma (TDP) ve eritrosit süspansiyonu (ES) grup-III' te anlamlı fark olacak şekilde uyguland. Grup-1 ve grup-2 deki hastalar genellikle taburcu edilirken, grup-III teki hastalar hastanede takip edildi.

Sonuç: Bu çalışma, kanama komplikasyonu olmayan yüksek INR düzeylerinde warfarin antikoagülasyonunun konservatif olarak yönetildiğini gösterdi. İntravenöz $\mathrm{K}$ vitamini warfarin antikoagülasyonu alan hastalarda küçük kanama komplikasyonlarında uygulandi.

TDP ve K vitamini büyük kanama komplikasyonlarıla birlikte yüksek INR düzeylerine sahip warfarin antikoagülasyonu alan hastalara uygulandi.

Anahtar Kelimeler: Warfarin, kanama, antikoagulasyon, vitamin $\mathrm{K}$. 


\section{Introduction}

Warfarin, a vitamin $\mathrm{K}$ antagonist, is an anticoagulant medication was recommended on prevention of the pulmonary embolism, venous thrombosis, thrombus formation on the mechanical heart valves and transient ischemic event prevention in atrial fibrillation (AF) (1). Warfarin restrains the clotting factors (II-VII-IX-X) and anticoagulant proteins $\mathrm{S}$ and C (2). The antithrombotic effect of warfarin is dependent on the clearance of prothrombin, and it presents on the fifth day of therapy $(1,2)$. Loading doses of warfarin, $7.5 \mathrm{mg}$ or more per day, might enhance the bleeding complications, by eliminating the clotting factor VII $(2,3)$, and could place the patients in a hyper-coagulable state because of reduction of protein $\mathrm{C}(2)$. On warfarin treatment, International normalized ratio (INR) monitoring should be analyzed daily until the INR is within the therapeutic range for the following two days. The target INR is $2.0-3.0$ for most warfarin indications. For mechanical mitral valve, the target INR is $2.5-3.0$ (4).

Bleeding is the risk related to long-term warfarin therapy (5) and rises significantly at INR values above $4.5(6,7)$. On chronic warfarin therapy, patients have hemorrhage risk $1 \%-3 \%$ per year, and it causes to hospitalization or death $(8,9)$. A review article demonstrated that the major bleeding risk was ranged from $0 \%-16 \%$, and fatal bleeding is $0 \%-2.9 \%$ in warfarin treatment patients (10). Hence, the management of high INR levels is essential (11). The goal of warfarin reversal is to elevate vitamin $\mathrm{K}$ related clotting factors (12), and it might be reversed by fresh frozen plasma (FFP), prothrombin complex concentrates (PCCs) or vitamin K $(12,13)$. Patients generally admit to the emergency department due to warfarin related complications. In this research, we aimed to evaluate the management of warfarin related bleeding complications in acute care patients.

\section{Material and Methods}

The study was designed as a cross-sectional and prospective observational design. From September 2018 to September 2019, a totally of 74 patients, with on warfarin treatment, who admitted to our acute care clinic were enrolled in the study. All patients underwent a detailed clinical examination and routine biochemistry. Inclusion criteria were warfarin anticoagulation and $>18$ years old. Exclusion criteria were the refusal to participate in the research study, severe hepatic dysfunction, defined as documented cirrhosis or upper limit of normal aminotransferases (at least five times), and known bleeding disorder.

Blood samples are gathered from the antecubital vein with an atraumatic puncture and are sent to the laboratory for analysis. Hematological parameters were analyzed by LH 780 analyzer (Beckman Coulter Inc, Miami, Florida). Hemoglobin, platelet count mean platelet volume, plateletcrit, and INR levels were recorded. $\mathrm{ABO}$ blood typing was performed using a hemagglutination technique (Biotest, Germany) according to the manufacture's protocol. Heart rate, respiratory rate, blood pressures, and body temperature were registered. Informed consent was received from participants before the investigation. This study was performed under the principles stated in the Declaration of Helsinki and accepted by the local Ethics Committee of the Hospital.

The patients were grouped into three groups based on INR levels. INR levels of the groups were $<3.0$ for Group-I, $3.0 \leq \mathrm{INR} \leq 5.0$ for Group-II and INR $>5.0$ for Group-III. Patients' medical history, medications, and warfarin related complications were recorded throughout the examination. A warfarin-related adverse event was described as bleeding in a patient taking warfarin. A major bleeding event was established as lethal bleeding; a reduction in hemoglobin greater than $20 \mathrm{~g} / \mathrm{L}$; bleeding that was intraspinal, intracranial, intraocular, intra-articular, retroperitoneal, pericardial or intramuscular with compartment syndrome; and/or bleeding that required operation or blood transfusion as per the International Society on Thrombosis and Haemostasis (14). In supra-therapeutic INR levels, warfarin dose held without administration of FFP or vitamin $\mathrm{K}$ in patients without bleeding complications. FFT, vitamin $\mathrm{K}$, or $\mathrm{ES}$ were performed in warfarin related bleeding complications. After the medical intervention, patients were transferred to the inpatient clinic for medical follow-up or further intervention.

Statistical Analyze: Data were investigated with SPSS software version 20.0 for Windows (SPSS Inc, Chicago, Illinois). The Kolmogorov-Smirnov test was applied to verify that continuous variables were normally distributed. Normally distributed variables were expressed as mean \pm standard deviation (SD), while non-normally distributed variables were shown as median with interquartile range (IQR). The categorical variables are displayed as percentages. Analysis of variance (ANOVA) was applied for normally distributed continuous data by the Tukey post hoc test. The nonparametric Kruskal-Wallis test was used to analyze continuous data with a nonnormal distribution. The frequencies of nominal variables were analyzed using the chi-square test or 
Fisher's exact test. Statistical significance was determined as $\mathrm{p}<.05$.

\section{Results}

The demographic and clinical data of the study population are presented in Table 1 . Table- 2 displays the clinical characteristics of the subjects. No difference was found in the demographic and clinical characteristics between the groups regarding gender, blood pressures, age, heart rate, and warfarin duration. First INR measurement was significantly higher in group-III than group-II and group-I, and in group-II than group-I $(\mathrm{p}<0.01)$. On the other hand, the second INR measurement was significantly higher in group-III than in group-II and group-I. Figure-1 represents the changes in first and second INR levels. In the hematological analysis, platelet counts and mean platelet volume were similar between groups. Plateletcrit and hemoglobin levels were significantly higher in group-I than group-III $(\mathrm{p}=0.01)$. Figure-2 presents the plateletcrit difference between groups. The medical history and medication usage were similar between the groups. Also, there was no statistically significant difference between the groups in blood group analysis. Table-3 shows the clinical evaluation of the study groups. Bruising was significantly higher in group-III than in group-II and group-I, whereas concussion and dyspnea were higher in group-II. Generally, group-I and group-II were evaluated without medical intervention, yet fresh frozen plasma (FFP) and erythrocyte suspension (ES) were given significantly in group-III. Patients in group-I and group-II were discharged commonly, and group-III subjects was followed-up in the hospital.

\section{Diiscussion}

This study demonstrated two major findings in patients with warfarin related complications in acute care settings. First, most of the patients were treated without the administration of vitamin $\mathrm{K}$, FFP, or ES in acute care settings. Second, FFP was more applied to patients with higher INR values (INR> 5.0).

Bleeding factors in subjects on warfarin anticoagulation associated with the intensity of anticoagulation, duration of anticoagulation therapy with simultaneous, interacting drug treatments, and patient-associated factors. Variability of anticoagulation was displayed to affect bleeding risk. An investigation by van Leuwen et al. revealed that variable anticoagulation enhanced the risk of bleeding 2.6-fold (15). In another study demonstrated that the bleeding risk was higher within the three months of anticoagulation in patients with higher target INRs and older patients. The most remarkable predictor of bleeding was an INR of $>4.5$ in the same study (6). Reducing the warfarin treatment in patients with atrial fibrillation, cerebral ischemia, or mechanical heart valves was reduced the bleeding risk and unfavorable events (16).

Some clinical factors such as age, polypharmacy, antiplatelet drug, warfarin duration, and higher target INR affect warfarin related bleeding complications. Warfarin complications increase when INR levels increases. The bleeding risk was higher in patients with mechanical heart valves due to higher ideal INR (2.5-3.0) (17). Aging is a known another factor for bleeding risk, and a study revealed that bleeding was increased twofold in older patients (18). A significant relationship was shown between polypharmacy and bleeding risk in elderly patients taking warfarin medication (19). The major bleeding risk raises twofold in patients on aspirin treatment in addition to warfarin anticoagulation (20). Fihn et al. demonstrated that duration of anticoagulation significantly influenced the bleeding risk (21). We presented that bleeding was increased with age and higher INR levels, but these findings were nonsignificant between study groups. Also, there was no association between warfarin duration, polypharmacy, and risk of bleeding in study groups. A possible explanation for this result might be associated with the small number of participants in the study groups.

Previous studies demonstrated that higher INR levels could be handled securely by withholding warfarin and regular monitoring $(22,23)$ in patients on warfarin treatment. Major bleeding was rare in patients at elevated INR, and conservative management was a reliable option. Warfarin reversal should be considered in patients on high bleeding risk, in whom with an INR $>9.0$ and low doses of vitamin $\mathrm{K}$ administration can be done (24). In minor bleeding complication, oral administration of vitamin $\mathrm{K}$ may correct the INR in $24 \mathrm{~h}$, and intravenous vitamin $\mathrm{K}$ can use for rapid correction $(6-8 \mathrm{~h})$. Also, oral or intravenous administration of vitamin $\mathrm{K}$ produces equal correction at $24 \mathrm{~h}(25,26)$. Rapid warfarin reversal is required with intravenous vitamin $\mathrm{K}$, FFP or prothrombin complex concentrates (PCC) in major bleeding. Generally, administration of FFP and vitamin $\mathrm{K}$ are achieved warfarin reversal. FFP is the most commonly used medication for rapid reversal of warfarin anticoagulant effects, and the patient's blood group needs to be established before administration (27). In the present study, We conservatively managed the patients with high INR levels and without bleeding complications. Vitamin $\mathrm{K}$ administration was applied in patients with minor bleeding and high INR levels. Also, We administrated FFP and intravenous 
Özdemir et al. / Management of warfarin complications

Table 1. Demographic and clinical characteristics of the study population

\begin{tabular}{|c|c|}
\hline & Patients $(n=74)$ \\
\hline Male $\%(n)$ & $43(32)$ \\
\hline Age (years) & $54.6 \pm 17.1$ \\
\hline Systolic BP (mm Hg) & $111.4 \pm 12.4$ \\
\hline Diastolic BP (mm Hg) & $70.5 \pm 7.0$ \\
\hline Heart rate (bpm) & $85.4 \pm 12.9$ \\
\hline Temperature (C) & $36.7 \pm 0.2$ \\
\hline Respiratory rate (rpm) & $14.3 \pm 1.5$ \\
\hline INR & $3.1(2.4-5.4)$ \\
\hline Platelet count $(103 / \mathrm{mm} 3)$ & $249.9 \pm 103.5$ \\
\hline Mean platelet volume. fL & $8.4 \pm 1.2$ \\
\hline Plateletcrit. $\%$ & $38.1 \pm 8.2$ \\
\hline Hemoglobin. g/dL & $12.8 \pm 2.8$ \\
\hline Second INR & $2.8 \pm 1.4$ \\
\hline Warfarin duration (years) & $2.4 \pm 1.1$ \\
\hline \multicolumn{2}{|l|}{ Medication } \\
\hline Warfarin only & $41(31)$ \\
\hline ASA $\%(n)$ & $43(32)$ \\
\hline Clopidogrel \%(n) & $2(2)$ \\
\hline NSAID \%(n) & $8(6)$ \\
\hline ASA and Clopidogrel \%(n) & $4(3)$ \\
\hline \multicolumn{2}{|l|}{ Medical History } \\
\hline Valve operation $\%(\mathrm{n})$ & $39(29)$ \\
\hline TIA $\%(n)$ & $8(6)$ \\
\hline DVT \%(n) & $17(13)$ \\
\hline Atrial fibrillation $\%(n)$ & $10(8)$ \\
\hline $\mathrm{PE} \%(\mathrm{n})$ & $9(7)$ \\
\hline $\mathrm{DVT}+\mathrm{PE} \%(\mathrm{n})$ & $1(1)$ \\
\hline Valve operation+TIA $\%(n)$ & $1(1)$ \\
\hline Sinus vein thrombosis $\%(n)$ & $1(1)$ \\
\hline Intracardiac thrombus $\%(\mathrm{n})$ & $9(7)$ \\
\hline Peripheral artery disease $\%(\mathrm{n})$ & $1(1)$ \\
\hline
\end{tabular}

INR, International normalized ratio; ASA, acetylsalicylic acid;

NSAID, Nonsteroidal antiinflammatory drug; TIA, transient ischemic attack; DVT, deep vein thrombosis; PE, pulmonary embolism

vitamin $\mathrm{K}$ in patients with major bleeding complications. Before the administration of FFP, the patient's blood group analyze was established. Also, we compare the blood groups in study groups, and we found that there was no significant difference between study participants regarding blood groups.

Clinicians should consider the advantages and disadvantages of medication before administration. Vitamin $\mathrm{K}$ related adverse events are anaphylaxis and coagulopathy with overcorrection. Volume overload is the major adverse effect of FFP. The thrombosis is the PCC' adverse effect when administered to reverse to the warfarin anticoagulation therapy in patients with high bleeding risk.

Limitations: This present study has some limitations. This was a single-center study and based on a small group of participants. The lack of PCC and oral vitamin $\mathrm{K}$ were other study limitations. We managed the patients in acute care settings, and the results of this study may not apply to outpatient clinic patients.

In conclusion, the present study demonstrates that warfarin anticoagulation at higher INR levels and without bleeding was managed by conservatively. Intravenous vitamin $\mathrm{K}$ was administered at minor bleeding in patients with warfarin anticoagulation. 
Table 2. Clinical characteristics of the study groups

\begin{tabular}{|c|c|c|c|c|}
\hline & GROUP-I $(n=41)$ & GROUP-II (n=13) & GROUP-III $(n=20)$ & $\mathrm{p}$ \\
\hline & INR $<3.0$ & $3.0 \leq \mathrm{INR} \leq 5.0$ & INR $>5.0$ & \\
\hline Male \%(n) & 41(17) & $53(7)$ & $40(8)$ & ns \\
\hline Age (years) & $51,1 \pm 18,0$ & $59,2 \pm 13,5$ & $58,9 \pm 16,2$ & 0.15 \\
\hline Systolic BP (mm Hg) & $113,7 \pm 10,9$ & $106,9 \pm 9,5$ & $109,5 \pm 15,9$ & 0.17 \\
\hline Diastolic BP (mm Hg) & $71,5 \pm 6,5$ & $68,1 \pm 4,3$ & $70,0 \pm 9,0$ & 0.30 \\
\hline Heart rate (bpm) & $85,2 \pm 12,4$ & $84,8 \pm 13,5$ & $86,4 \pm 14,0$ & 0.93 \\
\hline Temperature (C) & $36,7 \pm 0,3$ & $36,7 \pm 0,2$ & $36,7 \pm 0,2$ & 0.85 \\
\hline Respiratory rate (rpm) & $14,0 \pm 1,3$ & $14,6 \pm 1,9$ & $14,7 \pm 1,5$ & 0.13 \\
\hline INR & $2,4 \pm 0,6$ & $3,9 \pm 0,4 *$ & $15,8 \pm 12,6 *$ * & $<0.01$ \\
\hline Platelet count (103/mm3) & $253,0 \pm 113,8$ & $252,9 \pm 67,0$ & $241,6 \pm 104,8$ & 0.92 \\
\hline Mean platelet volume, fL & $8,4 \pm 1,0$ & $9,0 \pm 1,7$ & $8,1 \pm 1,0$ & 0.10 \\
\hline Plateletcrit, $\%$ & $40,6 \pm 7,1$ & $36,3 \pm 5,9$ & $34,2 \pm 10,1^{*}$ & 0.01 \\
\hline Hemoglobin, g/dL & $13,6 \pm 2,4$ & $12,0 \pm 2,1$ & $11,5 \pm 3,4^{*}$ & 0.01 \\
\hline Second INR & $2,2 \pm 0,6$ & $3,2 \pm 1,4$ & $3,7 \pm 2,0 *$ & $<0.01$ \\
\hline Warfarin duration (years) & $2,4 \pm 1,1$ & $2,6 \pm 1,1$ & $2,2 \pm 1,0$ & 0.45 \\
\hline Medication & & & & ns \\
\hline Warfarin only & $41(17)$ & $46(6)$ & $40(8)$ & \\
\hline ASA $\%(n)$ & $48(20)$ & $38(5)$ & $35(7)$ & \\
\hline Clopidogrel \%(n) & $2(1)$ & - & $5(1)$ & \\
\hline NSAID \%(n) & $2(1)$ & $15(2)$ & 15(3) & \\
\hline Asa and Clopidogrel \%(n) & $5(2)$ & - & $5(1)$ & \\
\hline Medical History & & & & ns \\
\hline Valve operation \%(n) & $41(17)$ & $46(6)$ & $30(6)$ & \\
\hline TIA \%(n) & 7(3) & $15(2)$ & $5(1)$ & \\
\hline DVT \%(n) & $20(8)$ & - & $25(5)$ & \\
\hline Atrial fibrillation $\%(\mathrm{n})$ & $10(4)$ & $15(2)$ & $10(2)$ & \\
\hline PE \%(n) & 7(3) & $8(1)$ & 15(3) & \\
\hline $\mathrm{DVT}+\mathrm{PE} \%(\mathrm{n})$ & - & - & $5(1)$ & \\
\hline Valve operation+TIA $\%(\mathrm{n})$ & - & - & $5(1)$ & \\
\hline Sinus vein thrombosis $\%(n)$ & - & - & $5(1)$ & \\
\hline Intracardiac thrombus $\%(n)$ & $15(6)$ & $8(1)$ & - & \\
\hline Peripheral artery disease $\%(\mathrm{n})$ & - & $8(1)$ & - & \\
\hline Blood Group & & & & ns \\
\hline Arh $+\%(n)$ & $20(8)$ & $23(3)$ & $37(7)$ & \\
\hline Arh- $\%(n)$ & $22(9)$ & $15(2)$ & - & \\
\hline $\mathrm{Brh}+\%(\mathrm{n})$ & $17(7)$ & $23(3)$ & 15(3) & \\
\hline Brh- \%(n) & $24(10)$ & $7(1)$ & - & \\
\hline $0 \mathrm{rh}+\%(\mathrm{n})$ & $5(2)$ & $15(2)$ & $30(6)$ & \\
\hline Orh- $\%(\mathrm{n})$ & $5(2)$ & $15(2)$ & $10(2)$ & \\
\hline $\mathrm{ABrh}+\%(\mathrm{n})$ & $5(2)$ & - & $5(1)$ & \\
\hline ABrh- $\%(n)$ & $2(1)$ & - & $5(1)$ & \\
\hline
\end{tabular}

INR, International normalized ratio; BP, Blood pressure; ASA, acetylsalicylic acid;NSAID, Nonsteroidalantiinflammatory drug; TIA, transient ischemic attack; DVT, deep vein thrombosis; PE, pulmonary embolism. *Group-I versus other study groups. ${ }^{\text {.T }}$ Group-II versus other study groups. p value significance $<0.05 \mathrm{~ns}$, non-significant. 
Özdemir et al. / Management of warfarin complications

Table 3. Clinical evaluation of the study groups

\begin{tabular}{|c|c|c|c|c|}
\hline & GROUP-I $(\mathrm{n}=41)$ & GROUP-II $(\mathrm{n}=13)$ & GROUP-III (n=20) & $\mathrm{p}$ \\
\hline & INR $<3.0$ & $3.0 \leq \mathrm{INR} \leq 5.0$ & INR $>5.0$ & \\
\hline \multicolumn{5}{|l|}{ Complaint } \\
\hline Gingiva bleeding \%(n) & $2(1)$ & $15(2)$ & $5(1)$ & ns \\
\hline GIS bleeding $\%(\mathrm{n})$ & $2(1)$ & - & $15(3)$ & ns \\
\hline Epistakxis \%(n) & $17(7)$ & $8(1)$ & $5(1)$ & ns \\
\hline Bruising \%(n) & $5(2)$ & - & $30(6) *$ & $<0.01$ \\
\hline Difficulty walking \%(n) & $2(1)$ & - & - & ns \\
\hline Dispnea \%(n) & $34(14)$ & $15(2) *$ & $-*$ & $<0.01$ \\
\hline Confusion $\%(\mathrm{n})$ & - & $23(3) *$ & - & $<0.01$ \\
\hline Mouth bleeding $\%(n)$ & - & - & $5(1)$ & $\mathrm{ns}$ \\
\hline Hematuria \%(n) & $10(4)$ & $8(1)$ & $20(4)$ & ns \\
\hline Abdominal pain $\%(\mathrm{n})$ & $5(2)$ & - & $10(2)$ & $\mathrm{ns}$ \\
\hline Abdominal pain and hematuri $\%(\mathrm{n})$ & - & $8(1)$ & - & ns \\
\hline Palpitation $\%(\mathrm{n})$ & $5(2)$ & $8(1)$ & - & ns \\
\hline Headache $\%(\mathrm{n})$ & - & - & $5(1)$ & ns \\
\hline Fever $\%(\mathrm{n})$ & $2(1)$ & - & - & ns \\
\hline Cough with bleeding $\%(\mathrm{n})$ & - & $8(1)$ & $5(1)$ & ns \\
\hline Pretibial edema $\%(n)$ & $12(5)$ & - & - & ns \\
\hline Vaginal bleeding \%(n) & $2(1)$ & $8(1)$ & - & ns \\
\hline \multicolumn{5}{|l|}{ Bleeding Site } \\
\hline No bleeding $\%(\mathrm{n})$ & $60(24)$ & $30(4)$ & $10(2)$ & ns \\
\hline Ecchymosis \%(n) & $7(3)$ & $8(1)$ & $30(6)$ & ns \\
\hline Bleeding gums $\%(n)$ & $5(2)$ & $15(2)$ & $5(1)$ & ns \\
\hline Hematuria $\%(\mathrm{n})$ & $10(4)$ & $8(1)$ & $20(4)$ & ns \\
\hline Epistaxis $\%(n)$ & $15(6)$ & $8(1)$ & $5(1)$ & ns \\
\hline Vaginal bleeding $\%(\mathrm{n})$ & - & $8(1)$ & $5(1)$ & $\mathrm{ns}$ \\
\hline GI bleeding \%(n) & $2(1)$ & $8(1)$ & - & $\mathrm{ns}$ \\
\hline Intracerebral bleeding $\%(\mathrm{n})$ & - & $8(1)$ & $20(4)$ & $\mathrm{ns}$ \\
\hline Intraabdominal bleeding $\%(\mathrm{n})$ & - & $8(1)$ & - & ns \\
\hline Hematuriaand Intraabdominalbleeding $\%(\mathrm{n})$ & - & - & $5(1)$ & $\mathrm{ns}$ \\
\hline \multicolumn{5}{|l|}{ Blood Product } \\
\hline No medication & $85(35)$ & $38(5) *$ & - *ゅ & $<0.01$ \\
\hline FFP & $2(1)$ & $8(1)$ & $35(7) *$ & $<0.01$ \\
\hline K vit & $7(3)$ & $30(4)$ & $20(4)$ & ns \\
\hline ES & $2(1)$ & - & - & $\mathrm{ns}$ \\
\hline $\mathrm{FFP}+\mathrm{ES}$ & $2(1)$ & $23(3) *$ & $30(6) *$ & $<0.01$ \\
\hline $\mathrm{FFP}+\mathrm{K}$ vit & - & - & $10(2)$ & ns \\
\hline $\mathrm{FFP}+\mathrm{ES}+\mathrm{K}$ vit & - & - & $5(1)$ & ns \\
\hline \multicolumn{5}{|l|}{ Treatment } \\
\hline Medical \%(n) & $10(4)$ & $54(7) *$ & $85(17) *$ & $<0.01$ \\
\hline Endoscopy \%(n) & $2(1)$ & - & $10(2)$ & ns \\
\hline Surgery $\%(\mathrm{n})$ & - & $8(1)$ & $5(1)$ & ns \\
\hline No intervention $\%(\mathrm{n})$ & $88(36)$ & $38(5) *$ & $-* \Psi$ & $<0.01$ \\
\hline \multicolumn{5}{|l|}{ Decision } \\
\hline Discharge $\%(n)$ & $68(28)$ & $38(5)$ & $10(2) *$ & $<0.01$ \\
\hline Follow-up \%(n) & $32(13)$ & $54(7)$ & $80(16) *$ & $<0.01$ \\
\hline Exitus \%(n) & - & $8(1)$ & $10(2)$ & $\mathrm{ns}$ \\
\hline
\end{tabular}

INR, International normalized ratio; GI, Gastrointestinal; FFP, Fresh frozen plasma; ES, Erythrocyte

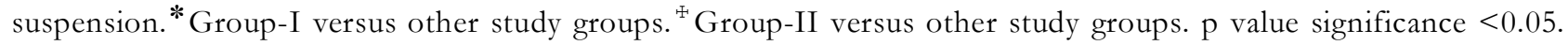
ns, non-significant. 


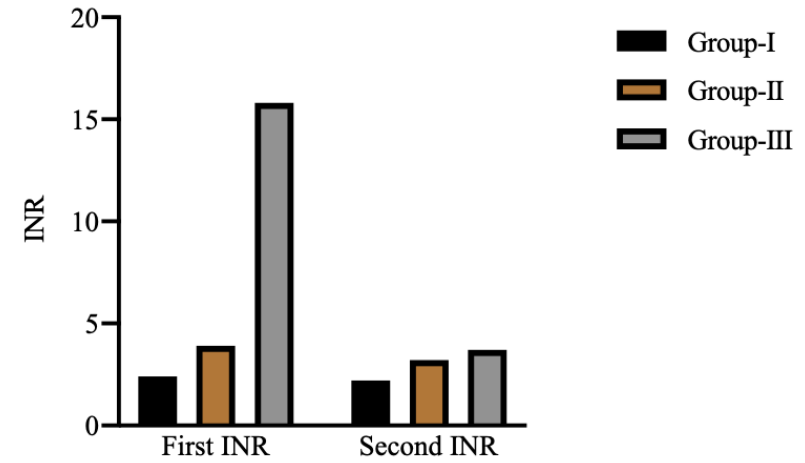

Fig. 1. Changes at INR (International normalized ratio) levels throughout warfarin anticoagulation management

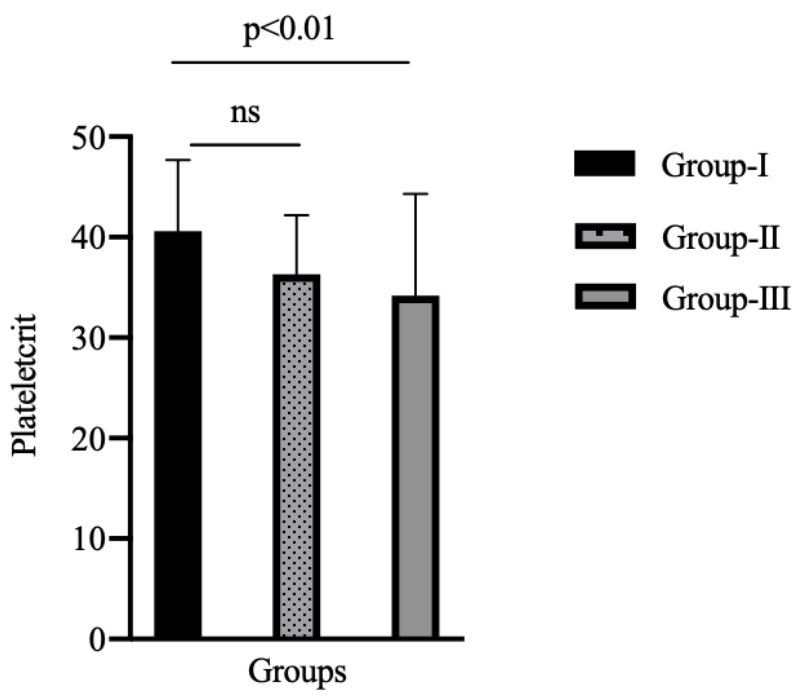

Fig. 2. Plateletcrit values between study groups. $p<0.05$ is significant

FFP and vitamin $\mathrm{K}$ were administered at the high INR levels with major bleeding in patients with warfarin anticoagulation.

Disclosure Statement: All authors have no declarations of interest to report.

\section{References}

1. Hirsh J, Dalen JE, Anderson DR, Poller L, Bussey H, Ansell J, et al. Oral anticoagulants: mechanism of action, clinical effectiveness, and optimal therapeutic range. Chest 1998; 114(5): 445S-469S.

2. Horton J, Bushwick B. Warfarin therapy: evolving strategies in anticoagulation. Am Fam Physician 1999; 59(3): 635-646.

3. Lamb GC. Loading dose of warfarin. JAMA 1997; 277(15): 1196-1196.

4. Whitlock RP, Sun JC, Fremes SE, Rubens FD, Teoh KH. Antithrombotic and thrombolytic therapy for valvular disease: antithrombotic therapy and prevention of thrombosis:
American College of Chest Physicians Evidence-Based Clinical Practice Guidelines. Chest 2012; 141(2): 576-600.

5. Landefeld CS, Beyth RJ. Anticoagulant-related bleeding: clinical epidemiology, prediction, and prevention. Am J Med 1993; 95(3): 315328.

6. Palareti G, Leali N, Coccheri S, Poggi M, Manotti C, D'Angelo A, et al. Bleeding complications of oral anticoagulant treatment: an inception-cohort, prospective collaborative study (ISCOAT). The Lancet 1996; 348(9025): 423-428.

7. Crowther MA, Ageno W, Garcia D, Wang L, Witt DM, Clark NP, et al. Oral vitamin K versus placebo to correct excessive anticoagulation in patients receiving warfarin: a randomized trial. Ann Intern Med 2009; 150(5): 293-300.

8. Linkins L-A, Choi PT, Douketis JD. Clinical impact of bleeding in patients taking oral anticoagulant therapy for venous thromboembolism. Ann Intern Med 2003; 139(11): 893.

9. Kearon C, Akl EA, Comerota AJ, Prandoni P, Bounameaux H, Goldhaber SZ, et al. Antithrombotic therapy for VTE disease: antithrombotic therapy and prevention of thrombosis: American College of Chest Physicians evidence-based clinical practice guidelines. Chest 2012; 141(2): 419-496.

10. Da Silva MS, Sobel M. Anticoagulants: to bleed or not to bleed, that is the question. In Elsevier 2002; 256-267.

11. Gallus AS, Baker RI, Chong BH, Ockelford PA. Consensus guidelines for warfarin therapy. Med J Aust 2000; 172(12): 600-605.

12. Makris M. Optimisation of the prothrombin complex concentrate dose for warfarin reversal. Thromb Res 2005; 115(6): 451-453.

13. Holbrook A, Schulman S, Witt DM, Vandvik PO, Fish J, Kovacs MJ, et al. Evidence-based management of anticoagulant therapy: antithrombotic therapy and prevention of thrombosis: American College of Chest Physicians evidence-based clinical practice guidelines. Chest 2012; 141(2): 152-184.

14. Schulman S, Kearon C, Subcommittee on Control of Anticoagulation of the Scientific and Standardization Committee of the International Society on Thrombosis and Haemostasis. Definition of major bleeding in clinical investigations of antihemostatic medicinal products in non-surgical patients. J Thromb Haemost 2005; 3(4): 692-694.

15. Van Leeuwen Y, Rosendaal F, Cannegieter S. Prediction of hemorrhagic and thrombotic events in patients with mechanical heart valve 
prostheses treated with oral anticoagulants. J Thromb Haemost 2008; 6(3): 451-456.

16. Torn M, van der Meer FJ, Rosendaal FR. Lowering the intensity of oral anticoagulant therapy: effects on the risk of hemorrhage and thromboembolism. Arch Intern Med 2004; 164(6): 668-673.

17. Cannegieter SC, Rosendaal F, Wintzen A, Van der Meer F, Vandenbroucke J, Briet E. Optimal oral anticoagulant therapy in patients with mechanical heart valves. $\mathrm{N}$ Engl J Med 1995; 333(1): 11-17.

18. Hutten BA, Lensing AW, Kraaijenhagen RA, Prins MH. Safety of treatment with oral anticoagulants in the elderly. Drugs Aging 1999; 14(4): 303-312.

19. Kagansky N, Knobler H, Rimon E, Ozer Z, Levy S. Safety of anticoagulation therapy in well-informed older patients. Arch Intern Med 2004; 164(18): 2044-2050.

20. Hart RG, Benavente O, Pearce LA. Increased risk of intracranial hemorrhage when aspirin is combined with warfarin: a meta-analysis and hypothesis. Cerebrovasc Dis 1999; 9(4): 215217.

21. Fihn SD, Callahan CM, Martin DC, McDonell MB, Henikoff JG, White RH. The risk for and severity of bleeding complications in elderly patients treated with warfarin. Ann Intern Med 1996; 124(11): 970-979.
22. Glover JJ, Morrill GB. Conservative treatment of overanticoagulated patients. Chest 1995; 108(4): 987-990.

23. Lousberg TR, Witt DM, Beall DG, Carter BL, Malone DC. Evaluation of excessive anticoagulation in a group model health maintenance organization. Arch Intern Med 1998; 158(5): 528-534.

24. Makris M, van Veen JJ, Maclean R. Warfarin anticoagulation reversal: management of the asymptomatic and bleeding patient. J Thromb Thrombolysis 2010; 29(2): 171-181.

25. Watson HG, Baglin T, Laidlaw SL, Makris M, Preston FE. A comparison of the efficacy and rate of response to oral and intravenous Vitamin $\mathrm{K}$ in reversal of over-anticoagulation with warfarin. Br J Haematol 2001; 115(1): 145-149.

26. Lubetsky A, Shasha Y, Olchovsky D, Loebstein R, Halkin H, Ezra D. Impact of pre-treatment INR level on the effect of intravenous low dose vitamin $\mathrm{K}$ in patients with excessive anticoagulation. Thromb Haemost 2003; 90(07): 71-76.

27. Ozgonenel B, O’Malley B, Krishen P, Eisenbrey A. Warfarin reversal emerging as the major indication for fresh frozen plasma use at a tertiary care hospital. Am J Hematol 2007; 82(12): 1091-1094. 